\title{
GENETIC DETERMINATION AND IMMUNOPATHOGENESIS OF TYPE 1 DIABETES MELLITUS IN HUMANS
}

\author{
Kantarova D. ${ }^{1}$, Vrlik M. ${ }^{2}$, Buc M. ${ }^{3}$ \\ ${ }^{1}$ Department of Internal Medicine, Comenius University, Jessenius Faculty of Medicine and University \\ Hospital, Martin, \\ ${ }^{2}$ Martin Centre of Immunology, Martin \\ ${ }^{3}$ Department of Immunology, Comenius University, Faculty of Medicine, Bratislava, Slovakia
}

\begin{abstract}
A b s t r a t
Type 1 diabetes comprises autoimmune-mediated and idiopathic beta-cell destruction of the pancreatic islets of Langerhans $\$$ resulting to absolute insulin deficiency. Susceptibility to T1D is influenced by both genetic and environmental factors. It is generally believed that environmental agents, such as viral infections, dietary factors in early infancy or climatic influences, trigger disease development in genetically susceptible individuals. Many candidate regions for diabetes genes have been reported, the insulin, glutamic acid 65, insuloma associated antigen 2, and zinc transporter ZnT8 genes being among the most important. The destruction of b cells is mediated mainly by cellular mechanisms; antibodies seem to reflect the ongoing autoimmune process only, not being directly involved in tissue damage. They, however, appear prior to the onset of insulin deficiency what makes us to profit from in prevention of the disease.
\end{abstract}

Keywords: type 1 diabetes mellitus, autoantigens, autoantibodies, regulatory T cells, HLA alleles.

\section{INTRODUCTION}

Diabetes mellitus is a group of metabolic disorders characterised by chronic hyperglycemia, with disturbances of carbohydrate, fat, and protein metabolism resulting from defects in insulin secretion, action, or both. Diabetes mellitus (DM) is a leading cause of blindness, amputations and end-stage renal disease, and is a major factor contributing to cardiovascular diseases and premature death. In 1979, the first general institutionalised classification of DM was accepted from ADA (American Diabetes Association), EASD (European Association for the Study of Diabetes) and NIH (National Institutes of Health). The insulin-dependent DM and non-insulin-dependent DM forms of diabetes mellitus became accepted. Later, the classification was updated. The four categories were proposed: type 1, type 2 (with a major component of insulin resistance, defined as non-insulin dependent diabetes mellitus), other types of diabetes (e.g. the maturity-onset diabetes of youth) and gestational diabetes (1) (Table 1).

Type 1 diabetes mellitus (T1D) is a condition caused by an autoimmune response against insulin-secreting $b$-cells of the pancreas resulting in their destruction. This autoimmune destruction is irreversible and the disease incurable. If new pancreas or islets are transplanted they too are destroyed, unless heavy immunosuppression is applied. T1D is usually characterised by acute onset and dependence on exogenous insulin for survival. In children, beta cell destructions is almost complete, in adults there remains a residual cell function for some years; this form was denominated "latent autoimmune diabetes" (LADA) $(2,3,4)$.

Address for correspondence

Daniela Kantarova, MD, PhD, Department of Internal Medicine, Comenius University, Jessenius Faculty of Medicine and University Hospital, Kollarova Str. N. 2, 03659 Martin, Slovakia

Phone: +421903524478; e-mail: daniela.kantarova@jfmed.uniba.sk 
Table 1 Diabetes mellitus classification (ADA 2010, modified)

\begin{tabular}{|l|}
\hline I. Type 1 diabetes \\
\hline A. Immune mediated \\
B, Idiopathic \\
\hline II. Type 2 diabetes \\
\hline III. Other specific types \\
A. Genetic defects of beta cell function \\
1. - 6 . MODY1 - MODY 6 \\
7. Mitochondrial DNA \\
8. Others \\
B. Genetic defects in insulin action \\
C. Diseases of the exocrine pancreas \\
D. Endocrinopathies \\
E. Drug or chemical-induced \\
F. Infections \\
G. Uncommon forms of immune-mediated diabetes \\
1. "Stiff man" syndrome \\
2. Anti/insulin receptor antibodies \\
H. Other genetic syndromes \\
\hline IV. Gestational diabetes mellitus \\
MODY - maturity onset diabetes of youth \\
\hline
\end{tabular}

\section{GENETICS}

Type diabetes mellitus is a genetically determined disease and many genes or genetic regions were found to be associated with its induction (for reviews see 5,6,7, www.tldbase.org). Several genome-wide linkage studies have been conducted to identify candidate regions that may contain unidentified susceptibility genes. About 50 candidate regions for diabetes genes have been reported in linkage studies of affected sib pairs. Most of the known or suspected susceptibility loci have been designated IDDM, e.g. IDDM1 refers to genes mapping to the HLA region at 6p21, IDDM2 to the insulin region at 11 pl5, etc. $(8,9)$ (Table 2).

HLA genes account for approximately 40\% of the genetic risk for the T1D development. The major determinant of genetic susceptibility to autoimmune diseases resides in the HLA class II region. Individuals with the highest risk for type 1A diabetes express both predisposing haplotypes: DQA1*05:01-DQB1*02:01 (DQ2), which is almost always inherited with DRB1*03:01 (DR3) and DQA1*03:01-DQB1 *03:02 (DQ8), inherited with DRB1*04:01 or DRB1*04:02 (DR4) $(9,10,11,12)$. These individuals have been referred to as DR3/DR4, DQ2/DQ8 heterozygotes. The genotype, DQ2/DQ8 (DR3/DR4), is commonly observed in type 1 diabetics. Individuals who carry this high risk haplotypic combination have $\sim 5 \%$ absolute risk of T1D, however within affected families, this genotype shows 20\% risk; approximately $40 \%$ of diabetic children possess this genotype compared to $2 \%$ of children in the healthy population $(7,10,13)$. Observations of transmission frequencies of particular haplotypes have helped to illustrate the importance of certain haplotypes in contributing to diabetes susceptibility. For example, analysis of the Human Biological Data Interchange (HBDI) family collection has revealed that DQA1*05:01-DQB*02:01 and DQA1*03:01DQB1*03:02 are transmitted to more than 80\% of diabetic children (9).

HLA-alleles have also been associated with protection from type 1A diabetes, esp. the haplotype DQA1*01:02/DQB1*06:02/DRB1*15:01 (DQ6, DR15) confers strong protection. Evidence suggests that such protection may be mostly encoded by the DQB1*06:02 allele; 
Table 2 T1D susceptibility loci

\begin{tabular}{|c|c|c|c|}
\hline Locus & Region & Locus & Region \\
\hline $\begin{array}{l}\text { IDDM1 } \\
\text { (HLA) }\end{array}$ & $6 \mathrm{p} 21$ & IDDM11 & $14 \mathrm{q} 24.3-14 \mathrm{q} 31$ \\
\hline IDDM2 & $11 \mathrm{p} 15$ & $\begin{array}{l}\text { IDDM12 } \\
\text { (CTLA-4) }\end{array}$ & 2q31-q33 \\
\hline IDDM3 & $15 q 26$ & IDDM13 & 2q34-q35 \\
\hline IDDM4 & $11 q 13$ & IDDM15 & $6 q 21$ \\
\hline IDDM5 & $6 q 25$ & $\begin{array}{l}\text { IDDM16 } \\
\text { (IGH) }\end{array}$ & $14 q 32$ \\
\hline IDDM6 & $18 q 12-q 21$ & IDDM17 & 10q25 \\
\hline IDDM7 & 2q31-33 & $\begin{array}{l}\text { IDDM18 } \\
(I L-12 p 40)\end{array}$ & $5 q 33$ \\
\hline IDDM8 & $6 q 27$ & & \\
\hline IDDM9 & $3 q 21-q 25$ & PTPN22 & $1 \mathrm{p} 13$ \\
\hline \multirow[t]{4}{*}{ IDDM10 } & $10 p 11-q 11$ & $?$ & $7 \mathrm{q} 25$ \\
\hline & & $?$ & $16 q 22-q 24$ \\
\hline & & $?$ & $1 q 42$ \\
\hline & & ? & $8 q 22-q 24$ \\
\hline
\end{tabular}

CTLA-4 - cytotoxic T lymphocyte antigen 4, HLA - major histocompatibility

complex of man, IDDM - insulin dependent diabetes mellitus, IgH - heavy chain of immunoglobulins, IL - interleukin, INS - insulin, PTPN - protein tyrosine

phosphatase non-receptor type 22

even in individuals heterozygous for one of the major HLA T1D-associated genes. Further, the rare T1D subject who does carry $\mathrm{DQB1}{ }^{*} 06: 02$ tends to develop disease at a later age, even in subjects who are positive for T1D autoantibodies $(7,14)$. To summarise, as some HLA haplotypes are associated with high, moderate, low risk and even "protection", their identification is useful in disease prediction (Table 3).

There are also some reports on associations between the last group of class II HLA alleles and T1D. HLA-DPB $1 * 0101$, -DPB $1 * 0301$, and -DPB $1 * 0202$, respectively, were reported to be positively and HLA-DPB1*0402 negatively associated with $(15,16,17)$.

The major role of HLA-associated genetic susceptibility is related to their central role in recessive (central) tolerance induction, antigen presentation and activation of $\mathrm{T}$ helper cell mediated immune response. High probability for loss of tolerance to specific islet peptides appear to depend upon the manner in which specific peptides bind to class II-presenting molecules and are recognised by $\mathrm{T}$ cell receptors. Poor peptide binding due to only partially filling the MHC groove is probably responsible for escape of autoreactive $\mathrm{T}$ cells from the thymus. In the periphery, an abundance of particular self-antigens, such as insulin in the islets, or modification of the antigen, should allow for sufficient presentation of odd binding epitopes to autoreactive T cells (18).

The second well established T1D susceptibility locus was mapped to the chromosome $11 \mathrm{p} 15.5$, to the insulin promoter region (IDDM2). The region is typical by its variable num- 
Table 3 Spectrum of diabetes risk HLA haplotypes

\begin{tabular}{|c|c|c|c|}
\hline \multicolumn{4}{|c|}{ High risk haplotypes } \\
\hline DR3 & DRB1*03:01 & DQA $1 * 05: 01$ & DQA1*05:01 \\
\hline \multirow[t]{3}{*}{ DR4 } & $\mathrm{DRB} 1 * 04: 01$ & DQA1*03:01 & DQA $1 * 03: 01$ \\
\hline & $\mathrm{DRB} 1 * 04: 02$ & DQA $1 * 03: 01$ & DQA $1 * 03: 01$ \\
\hline & DRB $1 * 04: 05$ & DQA $1 * 03: 01$ & DQA1*03:01 \\
\hline \multicolumn{4}{|c|}{ Moderate risk haplotypes } \\
\hline DR1 & DRB $1 * 01$ & DQA1*01:01 & DQB1*05:01 \\
\hline DR8 & DRB1*08:01 & DQA $1 * 04: 01$ & DQB1*04:02 \\
\hline DR9 & DRB1*09:01 & DQA1*03:01 & DQB1*03:03 \\
\hline \multicolumn{4}{|c|}{ Protective haplotypes } \\
\hline \multicolumn{4}{|c|}{ Strong protection } \\
\hline DR2 & $\mathrm{DRB} 1 * 15: 01$ & DQA1*01:02 & $\mathrm{DQB} 1 * 06: 02$ \\
\hline DR6 & DRB1*14:01 & DQA1*01:01 & DQB1*05:03 \\
\hline DR7 & $\mathrm{DRB} 1 * 07: 01$ & DQA $1 * 02: 01$ & DQB $1 * 03: 03$ \\
\hline \multicolumn{4}{|c|}{ Moderate protection } \\
\hline DR5 & $D R B 1 * 11: 01$ & $D Q A 1 * 05: 01$ & $D Q B 1 * 03: 01$ \\
\hline \multicolumn{4}{|c|}{ Weak protection } \\
\hline \multirow[t]{2}{*}{$D R 4$} & $D R B 1^{*} 04: 01$ & $D Q A I^{*} 03: 01$ & $D Q B 1 * 03: 01$ \\
\hline & $D R B 1^{*} 04: 03$ & $D Q A I^{*} 03: 01$ & $D Q B 1 * 03: 02$ \\
\hline$D R 7$ & $D R B 1 * 07: 01$ & $D Q A 1 * 02: 01$ & $D Q B 1 * 02: 01$ \\
\hline
\end{tabular}

ber of tandem repeat (VNTR) polymorphism. There are three classes of the VNTR polymorphism: VNTR I contains 26-63 repeating units (5' - - ACAGGGGTGGTGGGG - - - 3'), VNTR II 80 units, and VNTR III 140-210 units, respectively. Homozygous individuals with short VNTR elements develop T1D more likely than those with VNTR III; VNTRII is associated with resistance to the disease induction. The VNTR III genotype is associated with high expression of thymic proinsulin in thymic medullary epithelial cells, suggesting a correlation between antigen level and negative selection of high-avidity autoreactive $\mathrm{T}$ cells, consistent with a prominent role for recessive (central) tolerance in protection from insulin autoimmunity $(6,14)$. Recently, it has also been demonstrated that these individuals harbour a higher frequency of insulin-specific T cells by tetramer analysis when compared to individuals with the protective insulin VNTR element (19).

The next T1D susceptibility genetic region, IDDM12, is located on the long arm of chromosome 2 (2q33) and contains the gene coding for CTLA-4 (cytotoxic T lymphocyte antigen4). CTLA-4 plays an important role in regulation of the immune response, esp. in suppressive activities of $\mathrm{FOXP}^{+} \mathrm{CD}^{+} \mathrm{CD} 25^{+} \mathrm{T}$ regulatory cells. The genetic analyses and correlation 
of CTLA-4 gene haplotypes with messenger RNA levels suggest that it is a reduction in the amount of soluble CTLA-4 that is responsible for the increased susceptibility to T1D in T cells (20), including nTreg cells (21).

PTPN 22 (Protein tyrosine phosphatase non-receptor type 22; chromosome 1p13) is the fourth well established human DM 1A susceptibility gene. It encodes a lymphoid protein tyrosine phosphatase playing an important role in negative control of $\mathrm{T}$ cell activation and development $(22,23)$. In particular, it is critically involved in signaling of cytokines, such as IL-2 and IL-15. The T1D-associated variant of PTPN2 leads to diminished phosphorylation of STAT5 in T cells, interfering with cytokine signaling, raising the possibility that this variant may interfere with nTreg cell survival, which is highly dependent on IL-2 activity (24).

Interleukin 2 (IL-2) has paradoxical functions in T cells homeostasis, acting as a potent T cell growth factor during the initiation of immune responses and having a crucial function in the termination of $T$ cell responses and maintenance of self-tolerance. The latter function has been proposed to be due to a requirement for IL-2 signaling for the development and function of natural regulatory T cells. IL-2 could therefore take part in T1D pathogenesis. Really, it was reported that the region containing CD25 (IL-2RA; a chain of IL-2 receptor) on chromosome 10p14 was associated with the T1D (25). It is of interest that human linked T1D susceptibility segregates with 30\%-50\% decrease in the expression of CD25 pre-mRNA and surface protein on activated-memory $\mathrm{T}$ cells and, to a lesser extent, nTreg cells. Moreover, lower expression of CD25 in memory T cells from individuals with IL2RA susceptibility genotypes is associated with lower IL-2 secretion, which might synergise with lower expression of CD25 on nTreg cells to impair their function $(26,27)$. Because IL-2R signaling plays a key role in nTreg cell biology (28) and both the murine IL-2 and human IL2RA associations to T1D correlate with reduced expression of IL-2 and IL2RA, respectively, they may both operate by impairing nTreg cell development or function. Really, a recent study supports it as it found that defects in functional IL-2 signaling had an effect of FOXP3 expression (24). Thus, CD25 defects in patients with T1D may be mapping to a similar pathway as that, which leads to T1D in subjects with IPEX ${ }^{1}$.

More recently, the TLR7-TLR8 region of chromosome Xp22.2 has been mapped in T1D (7, www.tldbase.org). These genes encode intracellular receptors for viral RNAs and for DNA and RNA from apoptotic cells (29). This finding suggests that a variety of viral infections could, via increased type 1 interferon levels, enhance susceptibility to autoimmune b cell destruction and T1D, provided that susceptibility alleles at other loci are present. Seasonal differences in viral infections, combined with other seasonal effects such as reduced vitamin D levels in more northern countries during the winter months (30), could help to explain the well-established seasonality of T1D diagnosis itself.

A role of viruses in T1D development is further supported by the report of its association with IF1H1 (interferon induced with helicase C domain 1) gene (31). IF 1H1 codes for the pattern recognition receptor MDA5 (melanoma differentiation associated gene 5). It recognises certain types of double stranded RNAs, which are commonly produced during the replication of some RNA viruses. MDA5 is triggered also by enteroviruses, known as possible environmental triggers or accelerators of islet autoimmunity leading to type 1diabetes (32).

The association of enteroviruses (including entero-, echo- and coxsackie viruses) with T1D has attracted attention when reported that enterovirus infections had been diagnosed in $51 \%$ of cases and $28 \%$ of controls in the six months before the development of islet antibodies $(33,34)$. It was suggested that these viruses could stimulate a b-cell autoimmune response. Sequence similarity exists between the Coxsackie viral protein 2 (amino acid residues 249-279) and GAD65. This amino acid sequence homology is highly conserved in

${ }^{1}$ IPEX is an immunodeficiency syndrome caused by mutations in FOXP3 gene (Xp11.23q13.3.), which results to a breakdown of natural regulatory T cells (nTregs) development. It manifests itself by various autoimmune disorders, among them also with T1D. 
Coxsackie B4 isolates, and the relevant peptide has been found to bind to HLA-DR3 but not HLA-DR4 $(9,35)$. It was thought that these viruses induced activation and proliferation of T cells specific for the viral epitope that mimics a protein unique to $b$ cells (phenomenon of molecular mimicry) causing cytotoxic $\mathrm{T}$ cells to respond to the $\mathrm{b}$ cells autoantigens. However, further studies have proved that enteroviruses could be potentially causal at DM $1 \mathrm{~A}$ onset, but not at the initiation of islet autoimmunity $(36,37)$. The work of Winkler al al. (2011) further confirms this opinion (31). They, by examining individual islet autoantibodies, found no association with the development of IAAs or GADAs, which appear early in the disease process, and borderline association with IA-2As (31). It seems therefore that the development of T1D autoantibodies is strongly influenced by the HLA class II genotype, whereas progression to diabetes is rather connected to infections. So initiation of autoimmunity and progression to disease might be mediated by different mechanisms, first by failure of tolerance induction and second by molecular mimicry.

There are also some genes that confer resistance to T1D development. Except already mentioned HLA-DQ6, there is a form of IL-7R alpha gene (38) and a delta 32 variant of CCR5 (39) that were reported to be associated with protection, from T1D.

Genes not associated with T1D can also inform on its immunopathogenesis. In Crohn's disease, psoriasis, and other diseases a set of susceptibility loci encoding candidate genes with known functions in the $\mathrm{T}_{\mathrm{H}} 17$ pathway have been reported $(40,41)$. Using T1D database (www.t1dbase.org) and the current SNP association results, however, there is no evidence that these " $\mathrm{T}_{\mathrm{H}} 17$ genes" are associated with T1D. Hence, there is no support for a primary etiological role for this T cells subset in T1D. Also other genetic regions, such as $4 p 15.5$, 6q22.32, 7p15.2, 7p12.1, 10q23.31, 14q24.1, 16q23.1, 19q13.32, 20p11, 22q12.2, and Xq28 are known not to contain T1D functional candidate genes (7).

There are reports on other associations and one can expect that the genetic T1D map will be completely filled up in the near future.

\section{AUTOIMMUNE MECHANISMS IN DESTRUCTION OF BETA CELLS OF PANCREAS}

Type 1 diabetes mellitus results from progressive loss of pancreatic islet mass through autoimmunity targeted at diverse molecules that are expressed in the pancreatic $\beta$ cells. This chronic destructive process involves both cellular and humoral components of immunity. Once autoimmunity appears (evidenced by islet autoantibodies and progressive loss of insulin secretion) decades can elapse before the appearance of hyperglycaemia $(9,42)$.

The two distinctive features of type 1A diabetes are the infiltration of pancreatic islets by macrophages and lymphocytes and the presence of autoantibodies to various b cells antigens in the plasma $(43,44)$. Islet inflammation or insulitis is the hallmark lesion of T1D. Mononuclear cells, initially macrophages and dendritic cells accumulate first around the islets. Subsequently, B and T cells (both helper and cytotoxic) arrive and form a periinsulitis. Insulitis occurs when macrophages and activated $\mathrm{T}$ cells invade the islets of Langerhans $\$$ in the pancreas and attack the insulin-secreting $\beta$ cells. Insulitis occurs during the pre-diabetic phase ultimately leading to the complete depletion of $\beta$ cells $(35,45)$.

By far, T cells have been the one immune cell population that has consistently been shown to be critical for disease pathogenesis (46). T cells are known to infiltrate the islets in both rodent models of disease (NOD and $\mathrm{BB}$ ) and constitute a substantial fraction of infiltration observed in humans (47). Removal or the complete absence of mature $\mathrm{T}$ cells in the two rodent models prevents diabetes $(48,49)$. The pathogenic process is largely believed to be dependent upon the presence of autoreactive $\mathrm{CD} 8^{+}$and $\mathrm{CD} 4^{+} \mathrm{T}$ cell subsets. It is thought that $\mathrm{CD}^{+} \mathrm{T}$ cells may be more important during the early phases of pathogenesis, whereas $\mathrm{CD} 4^{+} \mathrm{T}$ cells are required throughout $(42,48,50)$.

Infiltration of autoreactive $\mathrm{T}$ cells into the islets is essential for the development of diabetes. Studies performed in NOD mice have revealed that the influx of T cells into the pan- 
creas is associated by de novo formation of lymphoid follicles what is a prototypic feature of a chronic progressive inflammation. The experimental results show that the interaction between membrane lymphotoxin (LTa1 $\beta 2$ ) of T cells and its receptor (LT $\beta R$ ) in membranes of stromal cells is essential for the development and maintenance of this lymphoid microenvironment. Lymphotoxin knockout mice and wild-type mice treated with LT $\beta$ receptorimmunoglobulin fusion protein (LT $\beta R$-Ig) reverse insulitis and prevent the formation of lymphoid follicles, even when insulitis is well established (51). This effect is likely caused by a failure to induce lymphoid tissue chemokines and adhesion molecules (52). In humans, LTA gene is polymorphic. From this point of view is interesting that LTA* 1 allele is in a linkage disequilibrium with HLA-A1, -B8, -DR3, the haplotype predisposing its carriers to T1D development (53).

The autoimmune process is initiated by activation of autoreactive $\mathrm{T}$ cells that escaped thymic negative selection and populated the peripheral lymphoid organs. Unknown insults trigger cell autoantigens shedding into the milieu. Antigen-presenting cells (APCs, i.e. dendritic cells, macrophages, and B cells) engulf them and start to migrate to the pancreatic lymph nodes (LNs). During their migration they process autoantigens and their split products, peptides, bind to groove of HLA molecules. When in LNs, they prime naive autoreactive $\mathrm{CD}^{+}$and $\mathrm{CD} 8^{+} \mathrm{T}$ cells. $\mathrm{CD} 8^{+} \mathrm{T}$ cells recognise peptide-HLA class I (pHLA) complexes in membranes of APCs and in the presence IL-2 and other cytokines, produced by autoreactive $\mathrm{CD}^{+} \mathrm{T}$ helper cells, become activated. They expand, differentiate into mature cytotoxic $\mathrm{T}$ cells, and migrate via the bloodstream into pancreatic islets, where they cause cell damage (18).

The resolution of severe insulitis by LTßR-Ig treatment (51) suggests that migration of inflammatory cells into the islets is a dynamic process in which these cells may constantly move in and out of the target tissue what results in continuous activation of autoreactive $\mathrm{T}$ cells by previously unrecognised autoantigens (epitope spreading) and tissue damage.

Many individuals with immunological markers of pre-clinical T1D do not progress to clinical disease. A possibility exists that such individuals may develop a successful regulatory immune response. However, a number of contradictory observations are reported in this field. Regulatory $\mathrm{T}$ cell numbers have been reported to be decreased or normal in T1D $(54,55,56)$, and functional assays have similarly described low, slightly decreased, or normal regulatory activity $(57,58,59)$. Much of these controversial findings results probably from methodological differences in various laboratories.

Macrophages by their production of reactive oxygen species and nitric oxide may have a destructive effect too. Activated macrophages produce also proinflammatory cytokines, esp. TNF and IL-1 (60), which are directly cytotoxic to $\beta$ cells (61). Moreover, $\beta$ cells themselves may be a source of IL-1 too, particularly in response to glucose, suggesting a destructive cycle in which hyperglycemia induces expression of the inflammatory mediators that results in immune activation and a further $\beta$ cell destruction (62).

Type I interferons (IFNs) secreted during early viral infection act in a paracrine manner to lower the permissiveness of neighbouring and distant cells to viral infection. During certain viral infections, early innate production of IFN- $\gamma$ may also contribute to the transition to an antiviral state. However, the IFN response not only lowers -cell permissiveness to viral (e.g. Coxackie viruses B4) infection, but also contributes to the escape from NK cell-dependent killing. These data raise the possibility that -cell responses elicited by interferons preserve self-tolerance of NK cells to pancreatic cells during a viral infection. Defective cell antiviral defences could therefore augment cellular damage and the release of otherwise sequestered cell antigens, providing a rich pool of epitopes to prime self-reactive lymphocytes and initiating autoimmunity (63).

iNKT cells are a population of T cells that share some characteristics with natural killer (NK) cells. The key features characteristic of iNKT cells include heavily biased T-cell receptor gene usage (Va24J $\alpha \mathrm{Q}$ and V $\beta 11$, so called V $\alpha 24 i$-NKT cells), CD1d restriction and high levels of cytokine production, particularly IL-4 and IFN- $\gamma$. Because of this property, NKT 
cells participate in regulation of the immune response; they can skew it into either $\mathrm{T}_{\mathrm{H}} 1$ or $\mathrm{T}_{\mathrm{H}} 2$ direction and so substantially contribute to the development of autoimmune processes. Several reports on iNKT cell analysis in type 1 diabetic patients have been published and there is no consensus since some authors described a decreased frequency and function of iNKT cells in these patients but it has not been confirmed by other investigators $(64,65)$. Despite this complexity of iNKT cell analysis in humans, it has been extensively shown that manipulations of iNKT cells prevent and even cure T1D in various mouse models (66).

Although T cells are the main players in the T1D field, B cells contribute to its pathogenesis too. NOD mice deficient in B cells, but displaying normal numbers of $\mathrm{T}$ cells, are prevented from developing disease (67). Treatment of both man (68) and NOD mice displaying the human CD20 molecule (69)with a B cell-specific anti-CD20 antibody alters progression to diabetes, again demonstrating the importance of B cells. Since B cells cannot transfer neither insulitis nor diabetes, they have been considered to fulfil a non-destructive, function. The role of B cells by way of their function as antigen-presenting cells in T1D etiology is now widely accepted (68). Nevertheless, autoantibodies can be detected in the plasma in $80 \%$ of patients; their appearance reflects the progression of autoimmunity to $\beta$ cells, their number is positively correlated with the evolution rate of autoimmune destruction. The presence of autoantibodies to just one of the four antigen groups alone is associated with only a marginal increase in risk. However, T1D risk is markedly increased when islet autoantibodies to two or more of the antigen groups are found in a child. In young, firstdegree relatives the 5-year risk of diabetes is of the order $<25 \%, 25-50 \%$, and $>50 \%$ if they have autoantibodies to one, two, and three islet autoantigens, respectively. In particular, the presence of antibodies to IA-2 (or ICA512 or IA-2b or PHOGRIN) is associated with highest risk $(14,42,70)$ (Table 4$)$.

Table 4 Type 1 diabetes risk

\begin{tabular}{|l|l|l|l|}
\hline \multicolumn{5}{|c|}{ Risk categories } & Very high \\
\hline Low & Intermediate & High & $\begin{array}{l}\text { Four islet antibodies; } \\
\text { higher titers }\end{array}$ \\
\hline $\begin{array}{l}\text { Single islet antibodies } \\
\text { with low affinity }\end{array}$ & $\begin{array}{l}\text { Single islet antibodies with } \\
\text { high affinity }\end{array}$ & $\begin{array}{l}\text { Two or three islet } \\
\text { antibodies }\end{array}$ & Young age \\
\hline Older age & Young age & Young age & Susceptible HLA genotype \\
\hline $\begin{array}{l}\text { Non-susceptible HLA } \\
\text { genotype }\end{array}$ & Susceptible HLA genotype & $\begin{array}{l}\text { Susceptible HLA } \\
\text { genotype }\end{array}$ & Impaired glucose tolerance \\
\hline
\end{tabular}

Moreover, the earlier autoantibodies appear, the faster the rate of progression to diabetes (71). Longitudinal studies of children born with high genetic risk of T1D showed that circulating autoantibodies to islet antigens can be seen as early as 6 months. A large proportion of childhood cases has seroconverted by the age of 3 years, and almost all cases by the age of 7 years, even although median age-at-diagnosis is approximately 12 years (4).

There is, however, no evidence that autoantibodies play a direct role in the pathogenesis of T1 D. Evidence against autoantibodies contributing directly to $\beta$-cell damage comes from studies of infants born to mothers with type 1 diabetes: anti-islet autoantibodies of mothers are transferred to the infants transplacentally, yet these infants do not develop disease. Moreover, about $10 \%$ of patients have no detectable antibodies at diagnosis (9).

Pancreatic $\beta$ cell components that are recognised by autoantibodies include mainly insulin or proinsulin, GAD65, IA-2, and ZnT8. Insulin was the first autoantigen identified in T1D 
and is still the only $\beta$ cell-specific. Insulin is derived from the enzymatic removal of a connecting peptide (C-peptide) from proinsulin within islet secretory granules and C-peptide is secreted along with insulin. In general, autoantibodies react to mature insulin, whereas specific proinsulin autoantibodies have been difficult to demonstrate. Antibodies against insulin (IAA) are ones of the earliest clinical markers of prediabetes. They can be detected in the sera of some $60 \%$ of newly diagnosed patients prior to insulin therapy. The presence of IAA is inversely correlated with age of diabetes onset, with almost $100 \%$ of newly diagnosed children less than 5 years of age expressing IAA, compared to less than $20 \%$ of those diagnosed after 15 years of age. Moreover, the levels of IAA are associated with the rate of the autoimmune destruction of the $\mathrm{b}$ cells making their detection an important aspect of diagnosis and prevention (42).

Glutamic acid decarboxylase of $\mathrm{M}_{\mathbf{r}} 65,000$ (GAD65) is an enzyme that converts glutamate to $\gamma$-amino butyric acid (GABA). It is expressed in human $\beta$ cells (but also by $\alpha$, and $\delta$ cells of the islets) and represents the major target autoantigen in type 1 diabetes. Antibodies to GAD65 can be detected in the sera of $75 \%$ of new-onset T1D patients. When GAD65 antibodies coexist with additional diabetes specific antibodies, they indicate a high risk; only GAD65-positive patients are slow progressors. LADA patients present frequently antiGAD65 antibodies only (72).

$60-75 \%$ of new-onset T1D patients have autoantibodies against the islet cell antigen 512 (ICA512 or IA-2), compared to only $2 \%$ of healthy controls. ICA512 is a tyrosine phosphatase-related molecule (it has no enzymatic activity) expressed in the pancreas and the brain. The molecule is produced in two alternative splice variants, with the variant usually termed IA2b (phogrin). Autoantibodies usually react with both variants, although about $10 \%$ of sera of new-onset patients reacts with one or the other (9). The presence of antibodies to IA-2 is associated with highest risk (14).

Zinc transporter ZnT8 was reported as a new T1D specific autoantigen recently. The ZnT8 molecule is within the membrane of islet $\beta$ cell secretory granules and transports zinc where it forms a complex with insulin. Autoantibodies were detected in $60-80 \%$ of newonset T1D compared with $<2 \%$ of controls. Individuals followed from birth to T1D showed ZnT8 antibodies as early as two years of age and generally emerged later than GADA and IAA. The combined measurement of ZnT8A, GADA, IA-2, and IAA raised autoimmunity detection rates to $98 \%$ at disease onset, a level that approaches that needed to detect a possible development of the disorder in a general children's population (73).

The above-mentioned autoantibodies appear in a sequential manner rather than simultaneously, with insulin and GAD65 usually appearing first. This appearance reflects the progression of humoral autoimmunity to $\beta$ cells. Longitudinal studies of children born with high genetic risk of $\mathrm{T} 1 \mathrm{D}$ showed that circulating autoantibodies to islet antigens can be seen as early as 6 months. A large proportion of childhood cases has seroconverted by the age of 3 years, and almost all cases by the age of 7 years, even although median age-at-diagnosis is approximately 12 years (7). The earlier autoantibodies appear, the faster the rate of progression to diabetes (71).

Childhood diabetes is characterised by early appearance of autoantibodies. Observations show that a second peak incidence period appears around puberty. The characteristics of the islet autoantibody profiles seen in "late" autoantibody-positive children are heterogeneous, and the typical profile is different compared to that seen in the 1 to 2 year olds. Autoantibodies to single antigen groups, typically, insulin or GAD65, without spreading to other islet proteins, is common. Lower-affinity IAAs or GAD65 antibodies are also more common, as are antibodies directed against atypical epitopes. Whereas early autoantibody development is strongly linked to T1D-associated HLA class II genotypes, the distribution of HLA class II genotypes in children who develop islet autoantibodies late is less dominated by HLA-DRB 1*04; DQB1*03:02 genotypes. This trend toward less HLA dominance and more heterogeneous antibody profiles is also pronounced in older individuals developing autoantibodies who lack a family history of T1D (14) (Table 5). One interpretation of the differences 
Table 5 Comparisons of neonate and puberty autoimmunity

\begin{tabular}{|l|l|}
\hline Neonate autoimmunity & Puberty autoimmunity \\
\hline Insulin/proinsulin reactive & Single antibodies to insulin or GAD65 \\
\hline DR3/DQ2 or DR4/DQ8 more common & Lower DR3/DQ2 or DR4/DQ8 prevalence \\
\hline $\begin{array}{l}\text { Early and frequent autoantibodies to } \\
\text { GAD65, IA-2, and ZnT8 }\end{array}$ & Less IA-2 and ZnT8 autoantibodies \\
\hline High affinity IgG1 autoantibodies & Presence of low affinity autoantibodies \\
\hline
\end{tabular}

associated with age of islet autoantibody appearance is that aetiology and immunisation are different, i.e. events that lead to an insulin-dominant spreading autoimmunity at the age of 1 year are different from those that lead to a GAD65-restricted autoimmunity at the age of 11 years or later. An intriguing possibility is that immune response thresholds for islet autoimmunity during childhood are programmed during foetal life.

\section{CONCLUSION}

It is now clear that T1D is caused by a complex autoimmune process that is triggered by ill-defined environmental factors in permissive genetic backgrounds. A constellation of gene variants scattered throughout the genome, generally operating via relatively small changes in expression and/or function, provides the basis for series of immune events that involve virtually every cell type of the immune system and eventually culminate in near complete loss of $\beta$ cells. Understanding this complexity is essential in the quest for a cure. Arrival of sophisticated technologies, techniques, refinement of statistical methods will surely bring new knowledge and will bring us to this goal.

\section{REFERENCES}

1. ADA. Diagnosis and classification of diabetes mellitus. Diabetes care 2010; 33 (Suppl 1): S62-69.

2. Aguilera E, Casamitjana R, Ercilla, G, Oriola J, Gomis R, Conget I. Adult-onset atypical (type 1) diabetes: additional insights and differences with type 1A diabetes in a European Mediterranean population. Diabetes Care 2004; 27: 1108-1114.

3. Atkinson MA, Eisenbarth GS. Type 1 diabetes: new perspectives on disease pathogenesis and treatment. Lancet 2001; 358: 221-229.

4. Todd JA, Knip M, Mathieu C. Strategies for the prevention of autoimmune type 1 diabetes. Diabet Med 2011; 28: $1141-1143$.

5. Kantarova D, Buc M. Genetic susceptibility to type 1 diabetes mellitus in humans. Physiol Res 2007; 56: 255-266.

6. Maier LM, Wicker LS. Genetic susceptibility to type 1 diabetes. Curr Opin Immunol 2005; 17 : 601-608.

7. Todd JA. Etiology of type 1 diabetes. Immunity 2010; 32: 457-467.

8. Jahromi MM, Eisenbarth GS. Genetic determinants of type 1 diabetes across populations. Ann New York Acad Sci 2006; 1079: 289-299.

9. Eisenbart GS. Diabetes and related autoimmune disease. 1035-1053. In: Rich RE (ed). Clinical Immunology. Principles and Practice. $3^{\text {rd }}$ ed. Philadelphia; Elsevier, 2008.

10. Concannon P, Rich SS, Nepom GT. Genetics of type 1A diabetes. New Engl J Med 2009; 360: $1646-1654$.

11. Nepom GT. HLA and type I diabetes. In: Lechler R, Warrens A (eds): HLA in health and disease. New York, Boston, London, Sydney, Tokyo, San Diego, San Francisco: Academic Press; 2000. p. 231-237.

12. Buc M, Bucova M, Javor J, Krivosikova M, Stuchlikova M, Shawkatova I, Michalkova D, Barak L, Jancova E, Petrek M. Associations between HLA class II alleles and type 1 diabetes mellitus in the Slovak population. Endocrine Regulations 2006; 40: 1-6.

13. Concannon P, Erlich HA, Julier C, Morahan G, Nerup J, Pociot F, Todd JA, Rich SS. Type 1 diabetes: evidence for susceptibility loci from four genome-wide linkage scans in 1,435 multiplex families. Diabetes 2005; 54: 2995-3001.

14. Ziegler AG, Nepom GT. Prediction and pathogenesis in type 1 diabetes. Immunity 2010; 32: 468-478. 
15. Noble JA, Valdes AM, Thomson G, Erlich HA. The HLA class II locus DPB1 can influence susceptibility to type 1 diabetes. Diabetes 2000; 49: 121-125.

16. Stuchlikova M, Kantarova D, Michalkova D, Barak L, Buc M. Association of HLA-DPB1 alleles with type I diabetes mellitus in Slovak population. Bratislava Med J 2006; 107: 73-75.

17. Valdes AM, Noble JA, Genin E, Clerget-Darpoux F, Erlich HA, Thomson G. Modeling of HLA class II susceptibility to Type I diabetes reveals an effect associated with DPB1. Genetic Epidemiol 2001; 21: 212-223.

18. Santamaria P. The long and winding road to understanding and conquering type 1 diabetes. Immunity 2010; 32: 437-445.

19. Durinovic-Bello I, Wu RP, Gersuk VH, Sanda S, Shilling HG, Nepom GT. Insulin gene VNTR genotype associates with frequency and phenotype of the autoimmune response to proinsulin. Genes Immunity 2010; 11: 188193.

20. Ueda H, Howson JM, Esposito L, Heward J, Snook H, Chamberlain G, Rainbow, DB, Hunter KM, Smith AN, Di Genova G. Association of the T-cell regulatory gene CTLA4 with susceptibility to autoimmune disease. Nature 2003; 423: 506-511.

21. Atabani SF, Thio CL, Divanovic S, Trompette A, Belkaid Y, Thomas D, Karp CL. Association of CTLA4 polymorphism with regulatory T cell frequency. Eur J Immunol 2005; 35: 2157-2162.

22. Bottini N, Musumeci L, Alonso A, Rahmouni S, Nika K, Rostamkhani M, MacMurray J, Meloni GF, Lucarelli $\mathrm{P}$, Pellecchia M et a. (2004) A functional variant of lymphoid tyrosine phosphatase is associated with type I diabetes. Nature Genetics 3: 337-338

23. Smyth D, Cooper JD, Collins JE, Heward JM, Franklyn JA, Howson JM, Vella A, Nutland S, Rance HE, Maier L. Replication of an association between the lymphoid tyrosine phosphatase locus (LYP/PTPN22) with type 1 diabetes, and evidence for its role as a general autoimmunity locus. Diabetes 2004; 53: 3020-3023.

24. Long SA, Cerosaletti K, Bollyky PL, Tatum M, Shilling H, Zhang S, Zhang, ZY, Pihoker C, Sanda S, Greenbaum C, Buckner JH. Defects in IL-2R signaling contribute to diminished maintenance of FOXP3 expression in CD4(+)CD25(+) regulatory T-cells of type 1 diabetic subjects. Diabetes 2010; 59: 407-415.

25. Vella A, Cooper JD, Lowe CE, Walker N, Nutland S, Widmer B, Jones R, Ring, SM, McArdle W, Pembrey ME. Localization of a type 1 diabetes locus in the IL2RA/CD25 region by use of tag single-nucleotide polymorphisms. Am J Human Genet 2005; 76: 773-779.

26. Dendrou CA, Plagnol V, Fung E, Yang JH, Downes K, Cooper JD, Nutland S, Coleman G, Himsworth M, Hardy M. Cell-specific protein phenotypes for the autoimmune locus IL2RA using a genotype-selectable human bioresource. Nature Genet 209; 41: 1011-1015.

27. Dendrou CA, Wicker LS. The IL-2/CD25 pathway determines susceptibility to T1D in humans and NOD mice. $\mathrm{J}$ Clin Immunol 2008; 28: 685-696.

28. Sakaguchi S, Miyara M, Costantino CM, Hafler DA. FOXP3+ regulatory T cells in the human immune system. Nature Rev Immunol 2010; 10: 490-500.

29. Sandor F, Buc M. Toll-like receptors. I. Structure, function and their ligands. Folia Biol 2005; 51: 148-157.

30. Svoren BM, Volkening LK, Wood JR, Laffel LM. Significant vitamin D deficiency in youth with type 1 diabetes mellitus. J Pediatrics 2009; 154: 132-134.

31. Winkler C, Lauber C, Adler K, Grallert H, Illig T, Ziegler AG, Bonifacio E. An interferon-induced helicase (IFIH1) gene polymorphism associates with different rates of progression from autoimmunity to type 1 diabetes. Diabetes 2011; 60: 685-690.

32. Witso E, Tapia G, Cinek O, Pociot FM, Stene LC, Ronningen KS. Polymorphisms in the innate immune IFIH1 gene, frequency of enterovirus in monthly fecal samples during infancy, and islet autoimmunity. PloS One 2011; 6: e27781.

33. Salminen K, Sadeharju, K, Lonnrot M, Vahasalo P, Kupila A, Korhonen S, Ilonen J, Simell O, Knip M, Hyoty $\mathrm{H}$. Enterovirus infections are associated with the induction of beta-cell autoimmunity in a prospective birth cohort study. J Med Virol 2003; 69: 91-98.

34. Yoon JW, Austin M, Onodera T, Notkins AL. Isolation of a virus from the pancreas of a child with diabetic ketoacidosis. The New England journal of medicine 1979; 300: 1173-1179.

35. Kukreja A, Maclaren NK. Autoimmunity and diabetes. J Clin Endocrinol Metabolism 1999; 84: 4371-4378.

36. Heino L, Lonnrot M, Knip M, Kupila A, Erkkila S, Toivonen A, Vahasalo P, Ilonen, J, Simell O, Hyoty H. No evidence of abnormal regulation of antibody response to coxsackievirus B4 antigen in prediabetic children. Clin Exp Immunol 2001; 126: 432-436.

37. Horwitz MS, Bradley LM, Harbertson J, Krahl T, Lee J, Sarvetnick N. Diabetes induced by Coxsackie virus: initiation by bystander damage and not molecular mimicry. Nature Med 1998; 4: 781-785.

38. Hoe E, McKay FC, Schibeci SD, Gandhi K, Heard RN, Stewart GJ, Booth DR. Functionally significant differences in expression of disease-associated IL-7 receptor alpha haplotypes in CD4 T cells and dendritic cells. $\mathrm{J}$ Immunol 2010; 184: 2512-2517.

39. Smyth DJ, Plagnol V, Walker NM, Cooper JD, Downes, K, Yang JH, Howson JM, Stevens H, McManus R, Wijmenga C. Shared and distinct genetic variants in type 1 diabetes and celiac disease. New Engl J Med 2008; 359: 2767-2777.

40. Abbas AK, Lichtman AH, Pillai S. Cellular and Molecular Immunology. Philadelphia; 7. Saunders, Elsevier, 2012: 545.

41. Buc M. Basic and Clinical immunology. Bratislava; Veda, 2012, in press (in Slovak). 
42. Stadinski B, Kappler J, Eisenbarth GS. Molecular targeting of islet autoantigens. Immunity 2010; 32: 446-456.

43. Achenbach P, Bonifacio E, Ziegler AG. Predicting type 1 diabetes. Curr Diabetes Rep 2005; 5: 98-103.

44. Haskins K, Bradley B, Powers K, Fadok V, Flores S, Ling X. Pugazhenthi S, Reusch, J, Kench J. Oxidative stress in type 1 diabetes. Ann New York Acad Sci 2003; 1005: 43-54.

45. Kent SC, Chen Y, Bregoli L, Clemmings SM, Kenyon NS, Ricordi C, Hering BJ, Hafler DA. Expanded T cells from pancreatic lymph nodes of type 1 diabetic subjects recognize an insulin epitope. Nature 2005; 435: 224228.

46. Anderson MS, Bluestone JA. The NOD mouse: a model of immune dysregulation. Annu Rev Immunol 2005; 23: 447-485.

47. Miyazaki A, Hanafusa T, Yamada K, Miyagawa J, Fujino-Kurihara H, Nakajima H, Nonaka K, Tarui S.Predominance of T lymphocytes in pancreatic islets and spleen of pre-diabetic non-obese diabetic (NOD) mice: a longitudinal study. Clin Exp Immunol 1985; 60: 622-630.

48. Christianson SW, Shultz LD, Leiter EH. Adoptive transfer of diabetes into immunodeficient NOD-scid/scid mice. Relative contributions of CD4+ and CD8+ T-cells from diabetic versus prediabetic NOD.NON-Thy-1a donors. Diabetes 1993; 42: 44-55.

49. Like AA, Biron CA, Weringer EJ, Byman K, Sroczynski E, Guberski DL. Prevention of diabetes in BioBreeding/Worcester rats with monoclonal antibodies that recognize T lymphocytes or natural killer cells. J Exp Med 1986; 164, 1145-1159.

50. Groen H, Klatter F, Pater J, Nieuwenhuis P, Rozing J. Temporary, but essential requirement of CD8+ T cells early in the pathogenesis of diabetes in BB rats as revealed by thymectomy and CD8 depletion. Clin Develop Immunol 2003; 10: 141-151.

51. Wu Q, Salomon B, Chen M, Wang Y, Hoffman LM, Bluestone J.A, Fu YX. Reversal of spontaneous autoimmune insulitis in nonobese diabetic mice by soluble lymphotoxin receptor. J Exp Med 2001; 193: 1327-1332.

52. Gommerman JL, Browning JL. Lymphotoxin/light, lymphoid microenvironments and autoimmune disease. Nature Rev Immunol 2003; 3: 642-655.

53. Valdes AM, Thomson G, Barcellos LF. Genetic variation within the HLA class III influences T1D susceptibility conferred by high-risk HLA haplotypes. Genes Immunity 2010; 11: 209-218.

54. Link M, Salur L, Kisand K, Rajasalu T, Tillmann V, Uibo R. Higher FoxP3 mRNA expression in peripheral blood mononuclear cells of GAD65 or IA-2 autoantibody-positive compared with autoantibody-negative persons. Apmis 2008; 116: 896-902.

55. Luczynski W, Stasiak-Barmuta A, Urban R, Urban M, Florys B, Hryszko M. Lower percentages of T regulatory cells in children with type 1 diabetes - preliminary report. Pediatric Endocrinol, Diabetes Metabolism 2009; 15: 34-38.

56. Vrabelova Z, Hrotekova Z, Hladikova Z, Bohmova K, Stechova K, Michalek J. CD 127- and FoxP3+ expression on $\mathrm{CD} 25+\mathrm{CD} 4+\mathrm{T}$ regulatory cells upon specific diabetogeneic stimulation in high-risk relatives of type 1 diabetes mellitus patients. Scand J Immunol 2008; 67: 404-410.

57. Long SA, Walker MR, Rieck M, James E, Kwok WW, Sanda S, Pihoker C, Greenbaum C, Nepom GT, Buckner JH. Functional islet-specific Treg can be generated from CD4+CD25- T cells of healthy and type 1 diabetic subjects. Eur J Immunol 2009; 39: 612-620.

58. Putnam AL, Brusko TM, Lee MR, Liu W, Szot GL, Ghosh T, Atkinson MA, Bluestone JA. Expansion of human regulatory T-cells from patients with type 1 diabetes. Diabetes 2009; 58: 652-662.

59. Schneider A, Rieck M, Sanda S, Pihoker C, Greenbaum C, Buckner JH. The effector T cells of diabetic subjects are resistant to regulation via CD4+ FOXP3+ regulatory T cells. J Immunol 2008; 181: 7350-7355.

60. Ferencik M, Stvrtinova V, Hulin I, Novak M. Inflammation - a lifelong companion. Attempt at a non-analytical holistic view. Folia Microbiol 2007; 52: 159-173.

61. Robles DT, Eisenbarth GS. Diabetes and related autoimmune diseases. In: Rich RR (ed.) Clinical Immunology, Principles and Practice, 2nd edn. London, Edinburg, New York, Philadelphia, St. Louis, Sydney, Toronto; Mosby, 2001. p.82.1-82.8.

62. Luo X, Herold KC, Miller SD. Immunotherapy of type 1 diabetes: where are we and where should we be going? Immunity 2010; 32: 488-499.

63. Flodstrom M, Maday A, Balakrishna D, Cleary MM, Yoshimura A, Sarvetnick N. Target cell defense prevents the development of diabetes after viral infection. Nature Immunol 2002; 3: 373-382.

64. Kukreja A, Costi G, Marker J, Zhang CH, Sinha S, Sun Z, Maclaren N. NKT cell defects in NOD mice suggest therapeutic opportunities. J Autoimmunity 2002; 19: 117-128.

65. Oikawa Y, Shimada A, Yamada S, Motohash, Y, Nakagawa Y, Irie J, Maruyama T, Saruta T. High frequency of valpha24(+) vbeta11(+) T-cells observed in type 1 diabetes. Diabetes Care 2002; 25: 1818-1823.

66. Diana J, Gahzarian L, Simoni Y, Lehuen A. Innate immunity in type 1 diabetes. Discovery Med 2011; 11: 513520.

67. Serreze DV, Chapman HD, Varnum DS, Hanson MS, Reifsnyder PC, Richard SD, Fleming SA, Leiter EH, Shultz LD. B lymphocytes are essential for the initiation of $\mathrm{T}$ cell-mediated autoimmune diabetes: analysis of a new "speed congenic" stock of NOD.Ig mu null mice. J Exp Med 1996; 184: 2049-2053.

68. Pescovitz MD, Greenbaum CJ, Krause-Steinrauf H, Becker DJ, Gitelman SE, Goland, R, Gottlieb PA, Marks JB, McGee PF, Moran AM. Rituximab, B-lymphocyte depletion, and preservation of beta-cell function. New Engl J Med 2009; 361: 2143-2152. 
69. Hu CY, Rodriguez-Pinto D, Du W, Ahuja A, Henegariu O, Wong FS, Shlomchik, MJ, Wen L. Treatment with CD20-specific antibody prevents and reverses autoimmune diabetes in mice. J Clin Inv 2007; 117: 3857-3867.

70. Bingley PJ, Gale EA. Progression to type 1 diabetes in islet cell antibody-positive relatives in the European Nicotinamide Diabetes Intervention Trial: the role of additional immune, genetic and metabolic markers of risk. Diabetologia 2006; 49: 881-890.

71. Hummel M, Bonifacio E, Schmid S, Walter M, Knopff A, Ziegler AG. Brief communication: early appearance of islet autoantibodies predicts childhood type 1 diabetes in offspring of diabetic parents. Ann Int Med 2004; 140: 882-886.

72. Hanzu F, Gomis R. Autoimmune diabetes mellitus. In: Shoenfeld Y, Cervera R, Gerschwin ME (eds) Diagnostic criteria in autoimmune diseases. Totowa; Hamana Press, 2008. p.241-249.

73. Wenzlau JM, Juhl K, Yu L, Moua O, Sarkar SA, Gottlieb P, Rewers M, Eisenbarth, GS, Jensen J, Davidson HW, Hutton JC. The cation efflux transporter ZnT8 (Slc30A8) is a major autoantigen in human type 1 diabetes. Proc Nat Acad Sci USA 2007; 104: 17040-17045.

Received: June, 20, 2012

Accepted: July, 10, 2012 